Marco Túlio Freitas Ribeiro

Marco Aurélio Camargo da Rosa

Rosa Maria Natal de Lima

Andréa Maria Duarte Vargas

João Paulo Amaral Haddad

Efigênia Ferreira e Ferreira

\section{Edentulism and shortened dental arch in Brazilian elderly from the National Survey of Oral Health 2003}

\section{Edentulismo e arco dental reduzido em idosos do Inquérito Nacional de Saúde Bucal 2003}

\begin{abstract}
OBJECTIVE: To describe the distribution of edentulism and estimate the prevalence of functional dentition and shortened dental arch among elderly population.
\end{abstract}

METHODS: A population-based epidemiological study was carried out with a sample of 5,349 respondents aged 65 to 74 years obtained from the 2002 and 2003 Brazilian Ministry of Health/Division of Oral Health survey database. The following variables were studied: gender; macroregion of residence; missing teeth; percentage that met the World Health Organization goal for oral health in the age group 65 to 74 years (50\% having at least 20 natural teeth); presence of shortened dental arch; number of posterior occluding pairs of teeth. The Chi-square test assessed the association between categorical variables. The Kruskal-Wallis and Mann-Whitney tests were used to assess differences of mean between number of posterior occluding pairs teeth, macro-region and gender.

RESULTS: The elderly population had an average of 5.49 teeth (SD: 7.93 ) with a median of 0 . The proportion of completely edentulous respondents was $54.7 \%$. Complete edentulism was $18.2 \%$ in the upper arch and $1.9 \%$ in the lower arch. The World Health Organization goal was achieved in $10 \%$ of all respondents studied. However, only $2.7 \%$ had acceptable masticatory function and aesthetics (having at least shortened dental arch) and a mean number of posterior occluding pairs of $6.94(\mathrm{SD}=2.97)$. There were significant differences of the percentage of respondents that met the World Health Organization goal and presence of shortened dental arch between men and women. There were differences in shortened dental arch between macroregions.

CONCLUSIONS: The Brazilian epidemiological oral health survey showed high rate of edentulism and low rate of shortened dental arch in the elderly population studied, thus suggesting significant functional and aesthetic impairment in all Brazilian macroregions especially among women.

DESCRIPTORS: Aged. Tooth Loss. Dental Health Surveys. Oral Health. 


\section{RESUMO}

OBJETIVO: Descrever a distribuição de edentulismo e estimar a prevalência de dentição funcional e arco dentário reduzido entre idosos.

MÉTODOS: Estudo epidemiológico populacional com 5.349 indivíduos de 65 a 74 anos do banco de dados do inquérito nacional de saúde bucal do Ministério da Saúde/Coordenação Nacional de Saúde Bucal em 2002 e 2003. Foram avaliados perda dentária; cumprimento à meta da Organização Mundial da Saúde para a faixa etária (50\% com pelo menos 20 dentes); presença de arco dental reduzido, número de pares em oclusão posterior; sexo e macroregião da residência. $\mathrm{O}$ teste qui-quadrado avaliou a associação entre variáveis categóricas. Os testes Kruskal-Wallis e Mann-Whitney foram usados para determinar diferenças do número médio de pares de dentes posteriores em oclusão, macro-região e sexo.

RESULTADOS: Os idosos tinham, em média, 5,49 dentes ( $\mathrm{DP}=7,93$ ) (mediana $=0$ ). A porcentagem de indivíduos totalmente edêntulos foi de $54,7 \%$. O edentulismo foi de $18,2 \%$ no arco superior e $1,9 \%$ no inferior. A meta da Organização Mundial da Saúde foi alcançada por $10 \%$ dos indivíduos; no entanto, 2,7\% tinham a função mastigatória e estética aceitáveis (com pelo menos o arco dental reduzido). Entre esses, o número médio de pares de oclusão posterior foi $6,94(\mathrm{DP}=2,97)$. A presença de arco dental reduzido foi mais freqüente entre homens, assim como o alcance da meta da Organização Mundial da Saúde. Também se observaram diferenças quanto ao arco dental reduzido entre as macro-regiões.

CONCLUSÕES: O levantamento epidemiológico de saúde bucal brasileira apresentou alto percentual de edentulismo e baixo de arco dental reduzido, sugerindo o comprometimento funcional e estético considerável em todas as regiões do País, especialmente entre mulheres.

DESCRITORES: Idoso. Perda de Dente. Inquéritos de Saúde Bucal. Saúde Bucal.

\section{INTRODUCTION}

Missing dental elements have a considerable impact on mastication, digestion, phonation, and aesthetics and have been associated with increased predisposition to geriatric diseases. ${ }^{3}$ Social, economic and cultural factors are associated with missing teeth in the oral cavity favouring the development of oral conditions, such dental caries and periodontal disease. In Brazil, a country with serious social disparities,,$^{15}$ an epidemiological oral health survey conducted in 2003 by the Brazilian Health Ministrya reported approximately 30 million edentulous individuals. Public oral health care services for adult population have historically focused urgent care, which often involves mutilating approaches such as dental extractions. ${ }^{2}$ Consequently, there is an increase in the decayed, missing and filled teeth index among individuals aged between 65 and 74 years due mainly to the higher rate of the missing teeth component.
The World Health Organization (WHO) $)^{8,27}$ established in 1982 a goal of $50 \%$ of individuals aged between 65 and 74 years having functional and aesthetic dentition with at least 20 natural teeth by the year 2000 . According to the WHO Report 826, there is no need for prosthetic replacement if an individual has 20 teeth without occlusal disharmony causing myofascial pain or temporomandibular joint disorders. ${ }^{27}$

The concept of a minimum of 20 teeth is supported by studies on acceptable functional and aesthetics dentitions. The concept of the shortened dental arch (SDA) has been developed as a treatment option for partially edentulous individuals. ${ }^{1,6,12}$ There is consensus that ten pairs of teeth are required in occlusion (20 teeth distributed from the $2^{\text {nd }}$ premolar to the $2^{\text {nd }}$ premolar in both arches). According to Witter et al, ${ }^{26}$ a SDA with three to five occlusal units or functional posterior

a Ministério da Saúde. Departamento de Atenção Básica. Projeto SB Brasil 2003: condições de saúde bucal da população brasileira 20022003. Brasilia, DF; 2004 
occluding pairs (POPs), with or without free-end removable partial dentures, provides sufficient occlusal stability for a prolonged period of time. Tsakos et $\mathrm{a}^{25}$ reported that the number of POPs is more related to oral health-related quality of life than the number of natural teeth. Sheiham \& Steele ${ }^{22}$ found that it was difficult to establish a relationship between nutrient intake and number and distribution of teeth; people with more than 20 natural teeth consumed more of major nutrients than those with fewer teeth; the intake of dietary fibers was higher in people with more teeth and significantly associated with the number of POPs. The SDA protocol de-emphasizes restorative treatment in the posterior regions of the mouth. The SDA avoids the risk of over-treatment while continuing to offer a high standard of care and minimizing cost. This seems to be a realistic approach when there is a high rate of dental caries and resources are limited.

The present study aimed to describe the distribution of edentulism and the prevalence of functional dentition and shorted dental arch among elderly individuals.

\section{METHODS}

A population-based study was carried out based on data from the 2002 and 2003 Brazilian Health Ministry/ National Coordination of Oral Health national oral health survey (the SB Brasil: Oral Health Status of the Brazilian Population). This study included individuals in the following age groups five to 12 years; 15 to 19 ; 35 to 44; and 65 to 74 years. A three-stage stratified cluster probability sampling design was used: Brazilian macro-regions $(\mathrm{n}=5)$, municipalities $(\mathrm{n}=250)$ and individuals $(\mathrm{n}=108,921)$. We considered a precision of $25 \%$ for five years and $20 \%$ for the remaining age groups, $95 \%$ confidence level and sample design effect of 2 for sample estimate.

A total of 2,000 public health providers performed all examinations. They participated in a previous calibration training (kappa coefficient). All examinations were performed between 2002 and 2003 at home, in schools and kindergartens using oral mirror plan and periodontal probes according to the WHO oral health surveys methodology (WHO 1997). In the age group of interest, 65 to 74 years old, 5,349 respondents were examined and clinical epidemiology data was collected on dental caries, periodontal disease, need of treatment, use and need for prosthesis.

The present study was based on data on missing teeth in elderly respondents. The dependent variables were tooth loss, the percentage that met the WHO dental goal, the presence of SDA and POPs..$^{1,5,12,24}$ The independent variables were gender and macro-region of residence. The third molars were excluded from the calculations.

The SDA was defined as having all anterior teeth, with a variation of three to five functional posterior occluding pairs of teeth. The number of functional posterior occluding pairs of natural teeth was calculated and scored as one for each pair of premolars in occlusion and two for each pair of molars in occlusion (Figure 1). An occluding pair of teeth consists of a tooth in the upper arch and the corresponding tooth in the lower arch that it bites against. The scores were totalled for the number of POPs.

The respondent characteristics and the prevalence of oral conditions were described. The chi-square test assessed the association between categorical variables. We used the Bonferroni correction for multiple comparisons. The Kruskal-Wallis and Mann-Whitney tests were used to determine differences of mean number of POPs by macroregions and gender. The level of significance was set at 0.05 for all tests. Data analyses were performed using SPSS version 15.0 for Windows.

The design effect was corrected, considering the stratified cluster sampling of the SB Brazil using Stata 10.0, svy command, to prevent overestimation of the results.

The study was approved by the National Research Ethics Committee ${ }^{27}$ (Process nr. 581/2000).

\section{RESULTS}

More than half (61.2\%) of the respondents were women. The respondents were distributed by macro-region

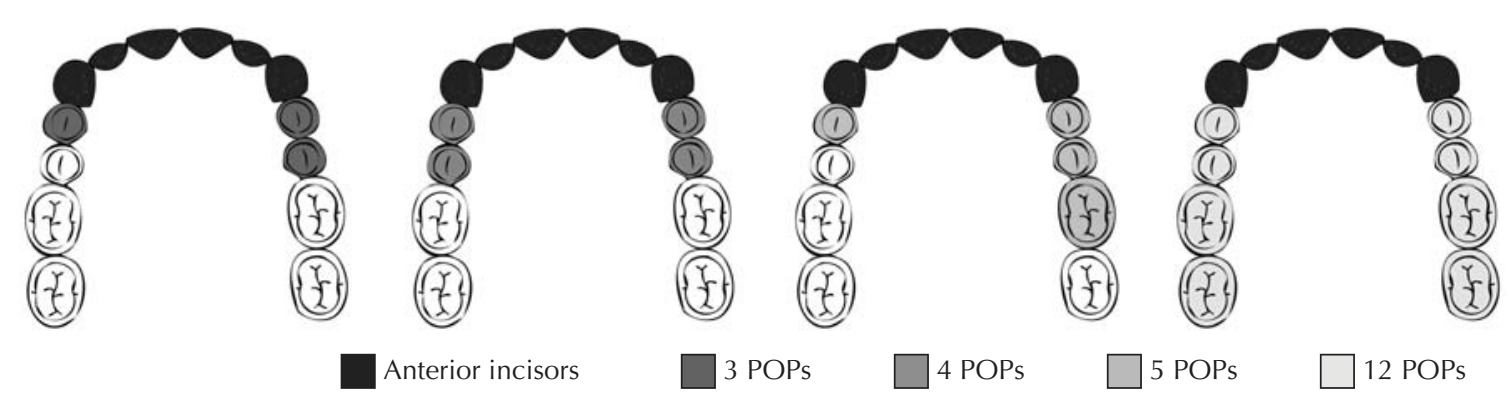

Figure 1. Schematic representation of posterior occluding pairs of teeth. 
Table 1. Distribution of remaining teeth in elderly respondents. Brazil, 2002-2003.

\begin{tabular}{|c|c|c|c|c|c|c|c|c|c|c|}
\hline \multirow{2}{*}{ Variable } & \multirow{2}{*}{$\mathrm{n}$} & \multirow{2}{*}{$\%$} & & \multirow{2}{*}{ Mean } & \multirow{2}{*}{ Median } & \multirow{2}{*}{ SD } & \multicolumn{4}{|c|}{ Shortened dental arch } \\
\hline & & & & & & & $\mathrm{n}$ & $\%$ & $\mathrm{n}$ & $\%$ \\
\hline \multirow{2}{*}{ With upper and lower teeth } & \multirow{2}{*}{1,343} & \multirow{2}{*}{25.1} & Upper & 8.0 & 8 & 4.2 & \multirow{2}{*}{143} & \multirow{2}{*}{10.7} & \multirow{2}{*}{53} & \multirow{2}{*}{$4 .($} \\
\hline & & & Lower & 8.9 & 9 & 3.4 & & & & \\
\hline \multirow{2}{*}{ No upper teeth } & \multirow{2}{*}{974} & \multirow{2}{*}{18.2} & Upper & - & - & - & \multirow{2}{*}{-} & & \multirow[t]{2}{*}{-} & \\
\hline & & & Lower & 6.5 & 6 & 2.9 & & & & \\
\hline \multirow{2}{*}{ No lower teeth } & \multirow{2}{*}{104} & \multirow{2}{*}{1.9} & Upper & 3.7 & 3 & 3.0 & \multirow{2}{*}{ - } & & \multirow[t]{2}{*}{-} & \\
\hline & & & Lower & - & - & - & & & & \\
\hline \multirow{2}{*}{ Complete edentulism } & \multirow{2}{*}{2,928} & \multirow{2}{*}{54.7} & Upper & - & - & - & \multirow{2}{*}{-} & & \multirow[t]{2}{*}{-} & \\
\hline & & & Lower & - & - & - & & & & \\
\hline \multirow{2}{*}{ Total } & \multirow{2}{*}{5,349} & \multirow{2}{*}{100.0} & Upper & 2.1 & - & 4.1 & \multirow{2}{*}{143} & \multirow{2}{*}{2.7} & \multirow{2}{*}{53} & \multirow{2}{*}{1.} \\
\hline & & & Lower & 3.4 & - & 4.5 & & & & \\
\hline
\end{tabular}

as follows: $14.0 \%$ in the Northern, $27.0 \%$ in the Northeastern, $13.7 \%$ in the Central-western, $19.7 \%$ in the Southeastern and $25.7 \%$ in the Southern. The proportion of complete edentulism was $53.8 \%$ and was lower in the lower arch than in the upper arch (2.0\% and $18.6 \%$, respectively). The overall sample had an average of 5.49 teeth (standard deviation, SD $=7.9$ ), with a median of zero. Of all, $10.0 \%$ met the WHO goal for the age group by 2000 . SDA was seen in $2.7 \%$ (Table 1$)$.

The Northeastern and Central-western regions had the highest proportion of elderly respondents with 20 or more natural teeth (Table 2). The lowest percentages were found in the Northern $(9.4 \%)$ and Southeastern regions $(9.4 \%)$. There were no statistically significant differences regarding the percentage that met WHO goal $(p=0.145)$ between macroregions. The percentage of respondents with more than 20 natural teeth was higher among men than women $(\mathrm{p}=0.001)$ (Table 2).
The considerable loss in masticatory function and aesthetics was common in all macroregions. There were differences in the presence of SDA among macroregions $(p=0.006)$. With the use of Bonferroni correction, the macroregions were divided into two groups: Northern, Northeastern and Southern (the worst results) and the Central-western and Southeastern regions (the best results).

SDA was significantly higher $(\mathrm{p}=0.000)$ among men than women (Table 2).

Among respondents with at least SDA, the mean number of POPs was $6.9(\mathrm{SD}=3.0)$, with a median of six and first quartile of four. The Central-western and Southern regions had the highest and lowest mean number of POPs, 7.5 and 6.1, respectively. The mean number of POPs was higher among men than women. No statistically significant differences in mean number of POPs were found among macroregions and gender (Table 3).

Table 2. Dental extraction in elderly Brazilian respondents by gender and macroregion. Brazil, 2002-2003.

\begin{tabular}{|c|c|c|c|c|c|c|c|c|}
\hline \multirow{2}{*}{ Variable } & \multicolumn{4}{|c|}{ WHO Goals $(\geq 20)^{*}$} & \multicolumn{4}{|c|}{ Shortened dental $\operatorname{arch}^{\mathbf{a}}$} \\
\hline & $\mathrm{n}$ & $\%$ & $95 \% \mathrm{Cl}$ & $p^{* *}$ & $\mathrm{n}$ & $\%$ & $95 \% \mathrm{Cl}$ & $p^{* *}$ \\
\hline \multicolumn{9}{|l|}{ Macroregion } \\
\hline North & 64 & 9.4 & $9.27 ; 9.47$ & \multirow{5}{*}{0.145} & 20 & 3.1 & $3.01 ; 3.13$ & \multirow{5}{*}{0.006} \\
\hline Northeast & 158 & 12.0 & $11.94 ; 12.04$ & & 23 & 1.8 & $1.79 ; 1.83$ & \\
\hline Central-west & 80 & 12.1 & $12.00 ; 12.22$ & & 27 & 4.0 & $3.94 ; 4.08$ & \\
\hline Southeast & 97 & 9.4 & $9.37 ; 9.43$ & & 43 & 4.0 & $4.01 ; 4.05$ & \\
\hline South & 138 & 10.3 & $10.22 ; 10.33$ & & 30 & 2.2 & $2.22 ; 2.28$ & \\
\hline \multicolumn{9}{|l|}{ Gender } \\
\hline Male & 316 & 14.0 & $13.99 ; 14.06$ & \multirow{2}{*}{0.001} & 83 & 3.6 & $3.58 ; 3.62$ & \multirow{2}{*}{0.001} \\
\hline Female & 221 & 7.3 & $7.31 ; 7.37$ & & 60 & 2.7 & $2.69 ; 2.73$ & \\
\hline
\end{tabular}

a Design effect

** Chi-square test

WHO: World Health Organization 
Table 3. Shortened dental arch and posterior occluding pairs by gender and macroregion. Brazil, 2002-2003.

\begin{tabular}{|c|c|c|c|c|c|c|c|c|c|c|c|c|c|}
\hline \multirow{3}{*}{ Variable } & \multicolumn{6}{|c|}{ Shortened dental arch } & & & & & \multicolumn{3}{|c|}{ Number of POPs } \\
\hline & \multicolumn{2}{|c|}{3 POPs } & \multicolumn{2}{|c|}{4 POPs } & \multicolumn{2}{|c|}{5 POPs } & \multicolumn{2}{|c|}{ 6-11 POPs } & \multicolumn{2}{|c|}{12 POPs } & \multirow[t]{2}{*}{ Mean } & \multirow[t]{2}{*}{ SD } & \multirow[t]{2}{*}{$p$-value } \\
\hline & $\mathrm{n}$ & $\%$ & $\mathrm{n}$ & $\%$ & $\mathrm{n}$ & $\%$ & $\mathrm{n}$ & $\%$ & $\mathrm{n}$ & $\%$ & & & \\
\hline \multicolumn{14}{|l|}{ Macroregion } \\
\hline North & - & & 9 & $0.9 \%$ & 1 & $0.1 \%$ & 6 & $0.6 \%$ & 4 & $0.4 \%$ & 7.2 & 2.9 & \multirow{5}{*}{$0.468^{*}$} \\
\hline Northeast & 6 & $0.4 \%$ & 5 & $0.3 \%$ & 1 & $0.1 \%$ & 8 & $0.5 \%$ & 3 & $0.2 \%$ & 7.3 & 3.1 & \\
\hline Central-west & 4 & $0.7 \%$ & 6 & $1.0 \%$ & 4 & $0.7 \%$ & 9 & $1.5 \%$ & 4 & $0.7 \%$ & 7.5 & 3.1 & \\
\hline Southeast & 15 & $2.4 \%$ & 11 & $1.8 \%$ & 6 & $1.0 \%$ & 3 & $0.5 \%$ & 8 & $1.3 \%$ & 6.91 & 3.11 & \\
\hline South & 11 & $0.7 \%$ & 7 & $0.5 \%$ & 4 & $0.3 \%$ & 7 & $0.5 \%$ & 1 & $0.1 \%$ & 6.10 & 2.61 & \\
\hline \multicolumn{14}{|l|}{ Gender } \\
\hline Male & 19 & $0.7 \%$ & 19 & $0.7 \%$ & 9 & $0.3 \%$ & 23 & $0.8 \%$ & 13 & $0.5 \%$ & 7.04 & 3.01 & \multirow{2}{*}{0.704 * * } \\
\hline Female & 17 & $0.7 \%$ & 19 & $0.7 \%$ & 7 & $0.3 \%$ & 10 & $0.4 \%$ & 7 & $0.3 \%$ & 6.82 & 2.94 & \\
\hline
\end{tabular}

\section{DISCUSSION}

Edentulism in Brazil (54.7\%) is more prevalent than in underdeveloped countries, such as African countries, and developed countries such as Spain, Italy, Iceland and Austria. According to Petersen \& Yamamoto, ${ }^{18}$ oral health status among elderly individuals varies both between and within countries. Such disparities are primarily related to living conditions and access to healthcare services. In addition to access, the type of treatment offered to the population affects the outcome, tooth preservation or not. The cohort effect regarding dental care practices to which the respondents examined in the present study had access must be considered. ${ }^{4}$

A study carried out with elderly individuals aged between 60 and 74 years in the city of Londrina, Southern Brazil, found a lower percentage of edentulism $(43.1 \%)$ than in general population $(54.7 \%)$. Rosa et $\mathrm{a}^{20}$ found that $65 \%$ of the elderly individuals were edentulous in the state of São Paulo, Southeastern Brazil. There are striking differences in oral health status among the elderly by macroregion of residence.

In a study carried out in Jönköping, Sweden, in 2003, individuals aged 70 years had on average, 21 teeth. In China, the mean number of teeth was 18.1 in elderly (65-74 years).${ }^{14}$ In the present study, the overall mean number of teeth was 5.49 with a median of zero, i.e., more than half of the elderly respondents were completely edentulous. Dental extractions mainly occurred in the upper arch: $18.2 \%$ had no teeth in the upper arch, compared to $1.9 \%$ with no teeth in the lower arch. One possible explanation for this difference is the presence of the ducts of the salivary glands, which encourage irrigation and mechanical cleansing of the region. ${ }^{16}$ Taiwo \& Omokhodion ${ }^{24}$ also found a greater retention of teeth in the lower arch among elderly individuals in Nigerian communities. The same is seen in Brazil, where the mean number of teeth among elderly respondents with only teeth in the upper $\operatorname{arch}(3.71)$ was lower than among those with only teeth in the lower arch (6.47). Colussi \& Freitas ${ }^{5}$ argue that dentistry practiced in Brazil has been mutilating for decades. There were performed 9.5 million extractions of permanent teeth and root remains in the Brazilian public care services in 2004. ${ }^{2,19,20}$

The WHO goal was not met in Brazil in 2003; only $10 \%$ had a minimum of 20 functional natural teeth. ${ }^{27}$ Countries such as Hungary (13\%), Spain $(28.1 \%)$ and Denmark (40\%) also failed to reach the WHO goal in individuals aged between 65 and 74 years according to a 2000 survey. ${ }^{4,13,17}$ This proportion rose to $22.6 \%$ in Hungary in 2004 and to $32.4 \%$ in Spain in 2005.,13

Among the elderly respondents, $2.7 \%$ met the SDA criteria in 2003. An epidemiological survey carried out in the United Kingdom showed that $2 \%$ of individuals between 65 and 74 years had SDA in $1988 .{ }^{9}$ In Canada, the SDA rate among individuals over 65 years was approximately $7.5 \%$ in $1992 .{ }^{11}$ SDA ensures masticatory function, occlusal support and dental arch stability for most elderly people. ${ }^{10}$ Ellias \& Sheiham ${ }^{7}$ concluded that maintaining a certain number of teeth (taking into account tooth position and condition) can provide greater satisfaction than replacing missing teeth with removable dentures.

Despite the small number of individuals with SDA, in the present study, approximately $25 \%$ of the respondents had a number of POPs that can appropriately prevent problems such as nutritional imbalance and impaired quality of life. Sheiham et $\mathrm{al}^{23}$ found that individuals with one to four POPs have more difficulty eating fibrous foods than those with more than five POPs. The present study showed that $98 \%$ of the respondents had considerably compromised 
masticatory function and aesthetics, which may affect their quality of life and health.

The gender distribution of the elderly respondents in the present study corroborates data from the 2000 Brazilian population census, confirming the greater longevity of women in this age group (43\% men and $57 \%$ women). ${ }^{\text {b }}$

The introduction of new assessment parameters could contribute to more effective planning of oral health care in the elderly. According to Scelza et al, ${ }^{21}$ this difference stems primarily from psychological factors - "courage" to make the decision to undergo a dental extraction. Moreover, women are more often primary caregivers, and they tend to engage in more self-care. In addition, women praise aesthetic factors more than men. The oral health assessment among elderly individuals in different regions showed that their basic oral functions were considerably compromised. The significant differences may be related to socioeconomic factors. The Northeastern region has considerably more economic and social problems and was the region with the worst results. The Southeastern region is the wealthiest one in Brazil and showed the best results in the analyses.

The use of the SDA and POPs as criteria for oral health evaluation instead of determining whether individuals

\section{REFERENCES}

1. Armellini D, von Fraunhofer JA. The shortened dental arch: a review of the literature. J Prosthet Dent. 2004;92(6):531-5. DOI:10.1016/S002239130400530X

2. Barbato PR, Nagano HCM, Zanchet FN, Boing AF, Peres MA. Perdas dentárias e fatores sociais, demográficos e de serviços associados em adultos brasileiros: uma análise dos dados do Estudo Epidemiológico Nacional (Projeto SB Brasil 20022003). Cad Saude Publica. 2007;23(8):1803-14. DOI:10.1590/S0102-311X2007000800007

3. Barbato PR, Peres MA. Tooth loss and associated factors in adolescents: a Brazilian population-based oral health survey. Rev Saude Publica. 2009;43(1):1325. DOI:10.1590/S0034-89102009000100003

4. Bravo M, Cortes J, Casals E, Llena C, Almerich-Silla JM, Cuenca E. Basic oral health goals for Spain 2015/2020. Int Dent J. 2009;59(2):78-82; quiz 62. DOI:10.1922/ IDJ_2035Cortés05

5. Colussi CF, Freitas SF. Epidemiological aspects of oral health among the elderly in Brazil. Cad Saude Publica. 2002;18(5):1313-20. DOI:10.1590/S0102311X2002000500024

6. De Sa e Frias V, Toothaker R, Wright RF. Shortened dental arch: a review of current treatment concepts. J Prosthodont. 2004;13(2):104-10. DOI:10.1111/j.1532849X.2004.04016.x have 20 natural teeth in the arches addresses both functional as well as aesthetic aspects of dentition, which have an impact on quality of life. The loss of anterior teeth is an aesthetic and psychosocial problem for most people, whereas the loss of posterior teeth may be a psychosocial problem for some individuals. There are marked variations in subjective measures of aesthetic and psychosocial comfort among people from different social backgrounds and regions, and between countries as well. ${ }^{10}$ Prosthetic rehabilitation parameters should be assessed to determine the individuals who could benefit from this treatment. These aspects should be further explored in epidemiological studies as the can provide valuable data for planning oral health services.

In 2004 Brazil drafted its first national oral health policy, known as "Smiling Brazil" program. One of its proposals was prosthetic replacement of extracted teeth. The aim of this policy is universal coverage, equity and comprehensive care to meet dental care needs of the population.

The Brazilian epidemiological oral health survey showed a high rate of edentulism and extensive need for rehabilitation treatment among elderly individuals. Providing this care becomes more urgent when considering that only $3 \%$ of the respondents showed adequate masticatory function and aesthetics.
7. Elias AC, Sheiham A. The relationship between satisfaction with mouth and number, position and condition of teeth: studies in Brazilian adults. J Oral Rehabil. 1999;26(1):53-71. DOI:10.1046/j.13652842.1999.00319.x

8. Global goals for oral health in the year 2000. Federation Dentaire Internationale. Int Dent J. 1982;32(1):74-7.

9. Gordon PH, Murray JJ, Todd JE. The shortened dental arch: supplementary analyses from the 1988 adult dental health survey. Community Dent Health. 1994;11(2):87-90.

10. Gotfredsen K, Walls AW. What dentition assures oral function? Clin Oral Implants Res. 2007;18 Suppl 3:3445. DOI:10.111/j.1600-0501.2007.01436.x

11. Hawkins RJ. The shortened dental arch: prevalence and normative treatment needs in a sample of older Canadian adults. Spec Care Dentist. 1998;18(6):24751.

12. Kayser AF. Shortened dental arches and oral function. J Oral Rehabil. 1981;8(5):457-62.

13. Madléna M, Hermann P, Jáhn M, Fejérdy P. Caries prevalence and tooth loss in Hungarian adult population: results of a national survey. BMC Public Health. 2008;8:364. DOI:10.1186/1471-2458-8-364

\footnotetext{
${ }^{\text {b }}$ Fundação Instituto Brasileiro de Geografia e Estatística Perfil dos idosos responsáveis pelos domicílios no Brasil 2000. Rio de Janeiro; 2002.
} 
14. Maki Y. Oral health care systems for elderly in Asia and Japan. Geriatrics Gerontol Int. 2004;4Suppl 1:S158-9. DOI:10.1111/j.1447-0594.2004.00255.x

15. Neri M. Políticas estruturais de combate à pobreza no Brasil. In: Henriques R, editor. Desigualdade e pobreza no Brasil. Rio de Janeiro: Instituto de Pesquisa Econômica Aplicada; 2000. p. 503-26.

16. Pereira AC, Castellanos RA, Silva RSC, Watanabe MGC, Queluz DP, Menghin MC. Oral health and periodontal status in brazilian elderly. Braz Dent J. 1996;7:97-102.

17. Petersen PE, Kjoller M, Christensen LB, Krustrup $U$. Changing dentate status of adults, use of dental health services, and achievement of national dental health goals in Denmark by the year 2000. I Public Health Dent. 2004;64(3):127-35. DOI:10.1111/j.1752-7325.2004.tb02742.x

18. Petersen PE, Yamamoto T. Improving the oral health of older people: the approach of the WHO Global Oral Health Programme. Community Dent Oral Epidemiol. 2005;33(2):81-92. DOI:10.1111/j.16000528.2004.00219.x

19. Roncalli AG. Levantamentos epidemiológicos em saúde bucal no Brasil. In: Antunes JLF, Peres MA, editors. Fundamentos de odontologia: epidemiologia em saúde bucal. Rio de Janeiro: Guanabara Koogan; 2006. p.32-48.

20. Rosa AGF, Castellanos RA, Pinto VG. Saúde bucal na terceira idade. Rev Gaucha Odontol. 1993;41(2):97102.
21. Scelza M, Pierro V, Scelza P, Zaccarro M, Rodrigues C. Status protético e alterações bucais dos pacientes do Programa Interdisciplinar de Geriatria e Gerontologia da UFF. Rev Bras Odontol. 2003;60(5):310-3.

22. Sheiham A, Steele J. Does the condition of the mouth and teeth affect the ability to eat certain foods, nutrient and dietary intake and nutritional status amongst older people? Public Health Nutr. 2001;4(3):797-803. DOI:10.1079/PHN2000116

23. Sheiham A, Steele JG, Marcenes W, Finch S, Walls AW. The relationship between oral health status and body mass index among older people: a national survey of older people in Great Britain. Br Dent J. 2002;192(12):703-6. DOI:10.1038/sj.bdj.480146

24. Taiwo JO, Omokhodion F. Pattern of tooth loss in an elderly population from Ibadan, Nigeria. Gerodontology. 2006;23(2):117-22. DOI:10.1111/ j.1741-2358.2006.00107.x

25. Tsakos G, Marcenes W, Sheiham A. The relationship between clinical dental status and oral impacts in an elderly population. Oral Health Prev Dent. 2004;2(3):211-20.

26. Witter DJ, de Haan AF, Käyser AF, van Rossum GM. A 6-year follow-up study of oral function in shortened dental arches. Part I: Occlusal stability. J Oral Rehabil. 1994;21(2):113-25.

27. World Health Organization. Recent advances in oral health: report of a WHO Expert Committee. Geneva; 1992. (WHO Technical Report Series, 826).

Study presented at the XVII World Congress of Epidemiology - VII Brazilian Congress of Epidemiology in Porto Alegre, Brazil, in 2008.

The authors declare no conflicts of interest. 